\title{
Determination of chemical elements and cross-section hardness of sclerotic darkened human dentin
}

\author{
Determinação de elementos químicos e da microdureza transversal da dentina esclerótica humana
}

Maurício Yugo de SOUZA ${ }^{1}$, Laura Celia Fernandes MEIRELLES ${ }^{1}$, Isabela Roberta Vieira DUQUE ${ }^{1}$, Mariane Cintra MAILART ${ }^{1}$, Taciana Marco Ferraz CANEPPELE ${ }^{1}$, Eduardo BRESCIANI ${ }^{1}$

1 - São Paulo State University (Unesp) - Institute of Science and Technology - São José dos Campos - Department of Restorative Dentistry - SP - Brazil.

\begin{abstract}
Objective: The aim of this study was to assess the amount of chemical elements (Ca, O, C, P, Fe, and $\mathrm{Mg}$ ) and the cross-section hardness of sclerotic darkened dentin in human teeth. Material and Methods: The study was approved by the local IRB and ten extracted teeth (five sound and five presenting sclerotic darkened dentin) were used. Tooth was sectioned mesiodistally and each half was used for each test. Amount of chemical elements (\%w) was determined by energy dispersive X-ray spectroscopy (EDS) in three different dentin areas (shallow, medium, or deep sound or sclerotic dentin). Knoop microhardness was determined at the same EDS areas. Data were analyzed by two-way ANOVA and multiple comparison tests, with significance level at 5\%. Results: No difference on microhardness was detected between sound and sclerotic dentin ( $\mathrm{p}=$ $0.743)$ and also among dentin depths $(\mathrm{p}=0.837)$. Lower Ca $(p=0.024)$ and higher C $(p=0.015)$ amounts were found at superficial sclerotic dentin. Increased Mg content ( $\mathrm{p}<0.001)$ was detected in sound dentin. Conclusion: It was concluded darkened sclerotic dentin presents similar cross-section microhardness to sound dentin. The assessed chemical elements were similarly present in sound or sclerotic dentin, except for $\mathrm{Mg}$, which was present higher concentration in sound dentin. Ca and $\mathrm{P}$ were lower in superficial sclerotic dentin.
\end{abstract}

\section{PALAVRAS-CHAVE}

Dentin; Hardness; Minerals; Tooth Remineralization.

\section{RESUMO}

Objetivo: O objetivo deste estudo foi avaliar a quantidade de elementos químicos ( $\mathrm{Ca}, \mathrm{O}, \mathrm{C}, \mathrm{P}, \mathrm{Fe}$ e $\mathrm{Mg}$ ) e a microdureza superficial da dentina esclerótica escurecida em dentes humanos. Material e Métodos: O estudo foi aprovado pelo Comitê de Ética local e dez dentes extraídos (cinco hígidos e cinco apresentando dentina esclerosada) foram utilizados. Os dentes foram seccionados no sentido mésiodistal e cada metade foi utilizada para cada teste. A quantidade de elementos químicos (\%w) foi determinada pela espectroscopia de raio-x por dispersão em energia (EDS) em três áreas dentinárias diferentes (superficial, média ou profunda). Estas mesmas áreas tiveram a microdureza superficial Knoop determinada. Os dados foram analisados por ANOVA dois fatores e teste de comparações múltiplas, com nível de significância de 5\%. Resultados: Nenhuma diferença quanto à microdureza foi detectada entre a dentina hígida e esclerótica $(\mathrm{p}=0,743)$ e nem em relação às profundidades ( $p=0,837)$. Menor quantidade de $\mathrm{Ca}(\mathrm{p}=0,024)$ e maior quantidade de $\mathrm{C}$ ( $p=0,015)$ foram encontradas na dentina esclerótica superficial. O aumento do conteúdo de $\mathrm{Mg}$ ( $\mathrm{p}<$ 0,001 ) foi detectado na dentina hígida. Conclusão: Pode-se concluir que a dentina esclerótica apresenta microdureza superficial similar à dentina hígida. Os elementos químicos estudados apresentaram-se igualmente para os dois tipos de dentina, exceto para o $\mathrm{Mg}$, o qual estava em maior quantidade na dentina hígida. O cálcio e o fósforo apresentaram quantidades reduzidas na dentina esclerótica superficial.

\section{KEYWORDS}

Dentina; Dureza; Minerais; Remineralização. 


\section{INTRODUCTION}

$\mathrm{C}$ aries is one of the most prevalent diseases in human population $[1,2]$ and restorative procedures for treating carious lesions are in constant development. Black previously established clinical protocols for amalgam cavity preparation focused on macromechanical retention, and material and tooth resistance $[3,4]$. The evolution of microbiological knowledge on caries disease and carious tissues [5] has allowed the use biocompatible materials that accelerate the remineralization process of mineral-deprived dental tissue, leading to greater preservation of sound structure [6-8].

The minimum intervention, reported in the 70's $[9,10]$, prioritizes the healing of caries affected tissue over the configuration of cavity design. In that technique, healing of carious dentin depends on remineralization, and clinically this substrate becomes hardened and often darkened $[6,11,12]$. The characterization of sclerotic dentin in vitro is reported to be related to the presence of transparent dentin underneath dentin carious lesion [13]. The assessment of that dentin is sometimes misinterpreted by evaluators and also by fluorescence measuring equipments $[8,14-16]$.

Despite the knowledge of the disease microbiology [11,17], dentin remineralizing potential, and properties of some restorative materials, the biological mechanisms of remineralization by the pulp-dentin complex are not fully understood.

To the best of our knowledge, there is no clear information on how arrested/sclerotic dentin darkens. The understanding regarding the mineral amount in sclerotic darkened dentin at different depths is important, considering inorganic and organic processes are taking place [18]. As the presence of darkened sclerotic dentin is the clinical confirmation parameter of the remineralization process [11,12], the assessment of chemical elements related to minerals present in dentin such as calcium and phosphorus [12], and those that would possibly be involved in the remineralization process such as iron and magnesium, would provide an insight for possible information on the path of dentin remineralization. By understanding the darkening in dentin sclerosis process, one would be able to improve the clinical protocols for achieving such condition in a faster, easier, or more effective manner.

Thus, the aim of this exploratory study was to compare the microhardness and chemical components of sclerotic darkened human dentin to sound dentin, within several depths.

\section{MATERIAL AND METHODS}

The present study was approved by the local Institutional Review Board (protocol \# 044241/2014). Ten teeth, being five sound and five with the presence of sclerotic darkened dentin, were used. The sclerotic darkened dentin resulted from very shallow cavities, restricted to the enamel dentin junction area. Teeth were collected in clinics in the local University, after informed written consent was given by patients.

Tooth crown was separated from root at the amelo-cementum level, and the remaining crown was sectioned mesiodistally into two halves. Cutting procedures were performed in a cutting machine, Labcut 1010 (Extec, USA). Tooth surface was polished in a polishing machine (Zwick, São Bernardo do Campo, São Paulo, Brazil), using sequential sandpaper discs with granulation up to 1200-grit.

The prepared tooth surface was photographed with a digital camera (Canon T3i) and $100 \mathrm{~mm}$ micro lens to guide the areas to be analyzed. Each tooth had a section evaluated for chemical element by Energy Dispersive X-ray Spectroscopy and the other section evaluated on Knoop microhardness (KHN).

\section{Knoop Microhardness analysis}

Half of each crown was subjected to microhardness analysis in a FM-700-Tech Future equipment. Indentation parameters were set at $10 \mathrm{~g}$ load for $10 \mathrm{~s} \mathrm{[19].}$ 
Prior to hardness assessment, the half crown submitted to KHN testing was embedded in plaster in order to achieve parallelism between the surface and the bottom of specimens. Delimitation of dentin depths, in relation to the pulp chamber (superficial, medium and deep), was guided by printed pictures, directing the operator in both performed tests. Dentin under the enamel-dentin junction or below dentin lesion, in the arrested dentin group, characterized the superficial dentin. Medium depth dentin was determined at the midway between the superficial dentin and the pulp chamber wall. Deep dentin area was set close to the pulp chamber wall.

The cross-section hardness was assessed at the three predetermined dentin areas; three indentations in each area were performed. The indentations mean represented the value of each dentin area studied.

\section{Energy Dispersive X-ray Spectroscopy (EDS) analysis}

The other half of the crown was subjected to EDS to determine the concentration (w\%) of chemical elements at the dentin thirds previously described. The opposing surface of hemi-crowns was ground in a polishing machine and specimen thickness was standardized at $4 \mathrm{~mm}$.

Specimens were fixed with carbon tape to a rigid base and submitted to EDS analysis using a Scanning Electron Microscope Inspect S50 (FEI). Three areas were evaluated in each sample, following previous delimitations. The chemical elements analyzed were: calcium, oxygen, carbon, phosphorus, magnesium and iron. The parameters used for EDS were: 20 kilovolts $(\mathrm{kV})$ accelerating voltage and $15 \mathrm{~mm}$ distance.

\section{Statistical design}

This study considered two independents variables, type of dentin (two levels: sound and sclerotic), and dentin depth (three levels: superficial, medium and deep). The dependent variables were the concentration of chemical elements ( $\mathrm{Ca}, \mathrm{C}, \mathrm{O}, \mathrm{P}, \mathrm{Fe}, \mathrm{Zn}, \mathrm{Cu}$, and $\mathrm{Mg}$ ) in weight $\%$ and dentin microhardness.
The results were statistically analyzed using the STATISTICA software (STATSOFT, version 8.0, 2010). Descriptive statistics consisted of mean and standard deviation values and inferential statistics consisted of normality tests, two-way ANOVA and Tukey's test. The significance level was set at $5 \%$.

\section{RESULTS}

The mean and standard deviation values of hardness in sound and sclerotic dentin are shown in Figure 1.

Two-way ANOVA revealed no statistical differences for dentin type $(\mathrm{p}=0.743)$ and for depth evaluated $(\mathrm{p}=0.837)$. The interaction of factors was also not significant $(\mathrm{p}=0.817)$.

The mean and standard deviation values of chemical elements quantity in sound and sclerotic dentin, according to assessed depth, are shown in Table 1.

According to the statistical analysis, lower $\mathrm{Ca}$ and $\mathrm{P}$ amounts $(\mathrm{p}=0.024$ and $\mathrm{p}=0.003$, respectively) were found at superficial sclerotic dentin. Higher C amount ( $p=0.015$ ) was found at superficial sclerotic dentin. Higher amount of

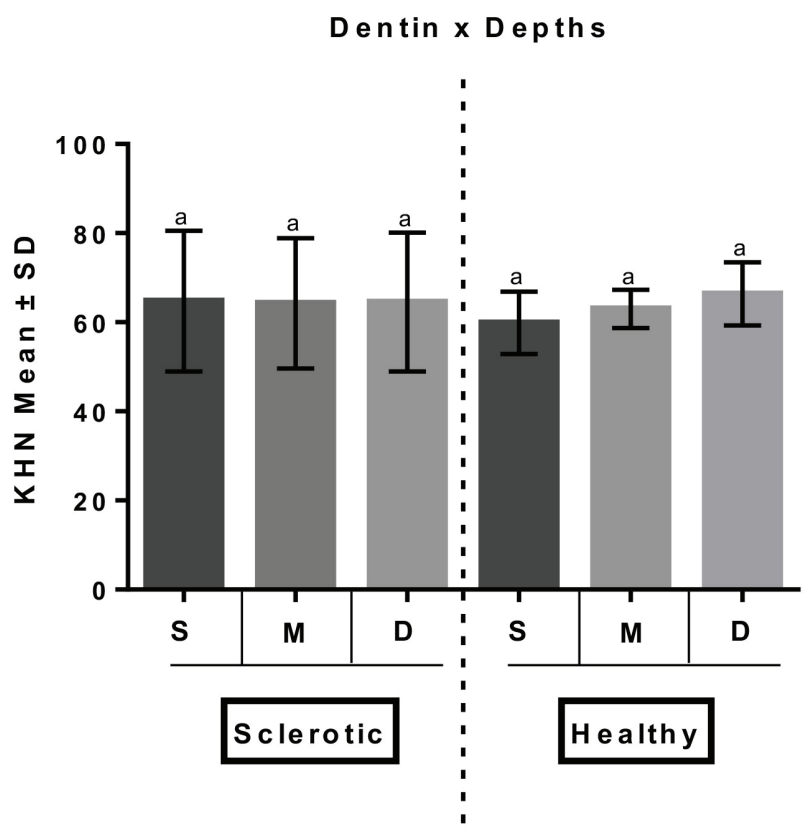

Figure 1- Mean and standard deviation according to the dentin type and depth analyzed. 
$\mathrm{Mg}$ was detected for sound dentin ( $\mathrm{p}<0.001)$, with increased concentration with increasing depth ( $<<0.001)$.
Representative EDS graphs of chemical elements quantification (in $\mathrm{w} \%$ ), for sclerotic (Figure 2) and sound (Figure 3) dentins follow.

Table I - Mean and standard deviation according to the each chemical element concentration in weight\%

\begin{tabular}{|c|c|c|c|c|c|c|c|}
\hline & Depth & MeanCa w\% $\%$ SD & Mean P w\% $\%$ SD & Mean $0 \mathrm{w} \% \pm \mathrm{SD}$ & Mean C w\% $\%$ SD & Mean Mg w\% $\%$ SD & Mean Fe w $\% \pm$ SD \\
\hline \multirow{3}{*}{$\begin{array}{c}\text { Sclerotic } \\
\text { Dentin }\end{array}$} & Superficial & $28.80 \pm 4.80^{\mathrm{a}}$ & $11.03 \pm 1.82^{\mathrm{a}}$ & $36.21 \pm 2.60^{a}$ & $23.63 \pm 7.02^{\mathrm{a}}$ & $0.27 \pm 0.10^{a}$ & $0.06 \pm 0.07^{a}$ \\
\hline & Medium & $34.11 \pm 2.31^{b}$ & $13.77 \pm 0.33^{b}$ & $35.76 \pm 0.96^{a}$ & $15.88 \pm 2.27^{b}$ & $0.46 \pm 0.06^{b}$ & $0.00 \pm 0.01^{a}$ \\
\hline & Deep & $33.79 \pm 2.60^{\mathrm{b}}$ & $13.88 \pm 0.76^{b}$ & $36.67 \pm 1.75^{a}$ & $14.85 \pm 2.24^{b}$ & $0.77 \pm 0.21^{c}$ & $0.04 \pm 0.05^{a}$ \\
\hline \multirow{3}{*}{$\begin{array}{l}\text { Sound } \\
\text { Dentin }\end{array}$} & Superficial & $33.59 \pm 1.05^{b}$ & $13.85 \pm 0.37^{b}$ & $35.95 \pm 1.30^{\mathrm{a}}$ & $15.89 \pm 2.02^{b}$ & $0.70 \pm 0.08^{c}$ & $0.02 \pm 0.02^{\mathrm{a}}$ \\
\hline & Medium & $34.38 \pm 1.05^{b}$ & $14.32 \pm 0.69^{b}$ & $34.78 \pm 0.71^{\mathrm{a}}$ & $15.91 \pm 1.65^{b}$ & $0.80 \pm 0.09^{d}$ & $0.01 \pm 0.02^{\mathrm{a}}$ \\
\hline & Deep & $31.58 \pm 2.43^{b}$ & $13.64 \pm 0.75^{b}$ & $37.31 \pm 1.53^{a}$ & $16.28 \pm 2.59^{b}$ & $1.02 \pm 0.14^{e}$ & $0.11 \pm 0.12^{\mathrm{a}}$ \\
\hline
\end{tabular}

Different letters denote differences within each chemical element assessed (within each column).

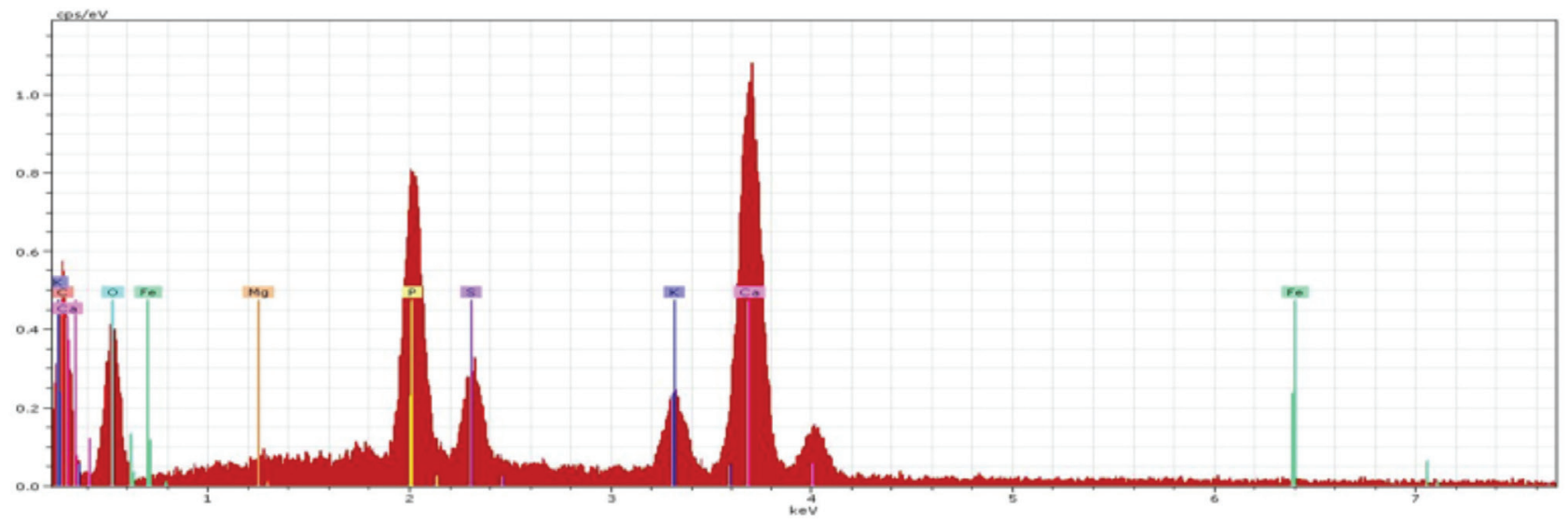

Figure 2 - Representative chemical composition of sclerotic darkened dentin.

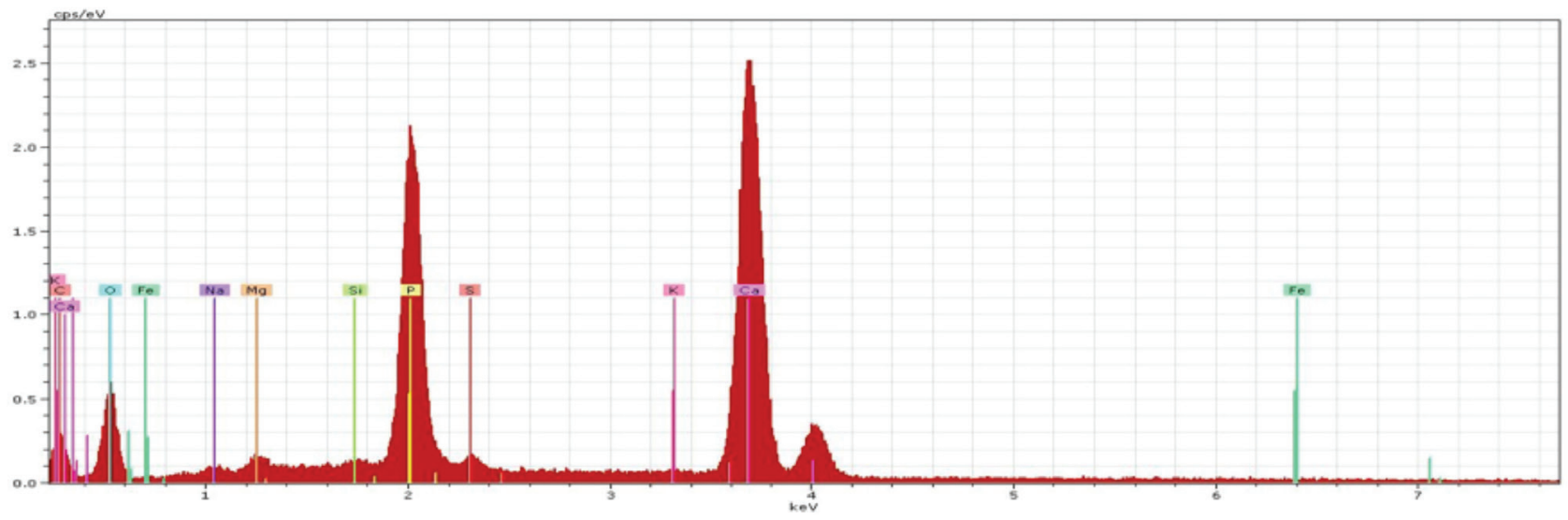

Figure 3 - Representative chemical composition of sound dentin. 


\section{DISCUSSION}

It is scientifically accepted dentin hardness is not only related to the mineral amount, but also to the distribution of peri and intertubular dentin and dentin tubules [20]. In this study there was no influence on microhardness according to dentin type, sound or sclerotic, and depth. The present results are similar to data presented in literature [21], but contrasting to others reporting sclerotic dentin presents lower hardness than sound dentin [22]. According Ogawa 1983 [23], the dentin right underneath carious dentin presents lower hardness than sound dentin and might not be called sclerotic dentin. The transparent dentin presents more minerals and consequently is harder. There is no consensus on the clinical determinants of sclerotic dentin; it is believed it is clinically dark and hard. This lack of standardization of sclerotic dentin, or even the lack of correlation between dentin morphology and hardness [21], might be responsible for differences in characterization of sclerotic dentin, as previously reported.

The results of this study seem appropriate since sclerotic dentin presented similar hardness to sound dentin. In clinical scenarios, sclerotic dentin is assumed to be harder as it is generally compared to carious dentin, leading to the impression sclerotic dentin would be very hard and harder than sound dentin. The lower hardness values reported in the literature for the superficial layer of sclerotic dentin might be explained by the difficulty in determining the presence of sclerotic dentin or demineralized dentin by caries process. It is important to highlight that sclerotic dentin represents success if considering the arresting (hardening and dakening) of dentin lesion, fact detected in stepwise carious removal studies $[24,25]$. Thus understanding such successful scenario would improve clinical protocols in accelerating such process.

As previously stated, microhardness assessment is not fully correlated to mineral content in dentin, as the amount of intertubular and intratubular dentin, and also the amount of tubules influence the results. A microradigraphy assessment could be used, as its correlation to mineral content is stronger, highlighting a possible limitation of the present study. On the other hand, studies assessing sclerosis of dentin usually determine their hardness characteristics using microhardness testing.

As dentin darkening is often the clinical parameter to determine the presence of sclerotic dentin, fact previously reported on stepwise excavation studies, we assume that understanding the mechanism of dentin being sclerotic and dark would improve and optimize current protection protocols of the pulp-dentin complex. That mechanism could be related to mineral composition or chemical elements in sclerotic dentin, guiding or as a result of that process [26]. Based on that supposition, the present study also focused on chemical elements of sclerotic dentin.

For calcium (Ca) amount, there was no influence of dentin type or depths evaluated. The statistical analysis revealed interaction of both factors, as the superficial dentin in the sclerotic group presented lower concentration of $\mathrm{Ca}$ in weight \%. Previous studies have reported the mineral composition of sclerotic dentin [27-30], with lower concentration of calcium compared to sound dentin. Those results are consistent with dental caries pathology, more specific to the demineralization process, which is characterized by mineral loss [28,31,32]. Calcium concentration may also vary according to age, gender, location and environmental factors [29,30,33,34].

Phosphorus (P) presented significant interaction of factors (dentin type and depth), with similar amount in the different depths for sound dentin, while lower amount was detected at the superficial dentin within the sclerotic dentin group. These data are in agreement with calcium data obtained, and are possibly related to the inclusion of carious / demineralized dentin in this analysis [26].

The non-linear correlation between mineral content and hardness of dentin [35-37] in specific scenarios, such as under 
demineralization and remineralization processes, might be another explainion of the lack o correlation between calcium and phosphor data with hardness data at superficial sclerotic dentin.

A decreasing pattern of mineral content in dentin toward to the pulp [38] was not detected for any hydroxyapatite-related chemical elements studied ( $\mathrm{Ca}$ and $\mathrm{P}$ ).

Oxygen was studied because higher values were found in sclerotic dentin in the pilot study (data not presented). This possible increase suggests collagen oxidation on sclerotic area, resulting in darkening [39]. Unfortunately, oxygen increase was not detected in this study.

Regarding the Carbon (C) amount, there was no difference for dentin type (sclerotic $\mathrm{x}$ sound). Differences were detected for dentin depth and also for the interaction of factors interaction (dentin type and depth). The superficial dentin showed greater Carbon w\% compared to other depths within sclerotic dentin group. That observation is also possibly related to mineral loss in superficial sclerotic dentin, which leads to increase in organic components that present carbon in their structure.

Lower magnesium (Mg) amount present in sclerotic dentin is in agreement with literature data [40]. $\mathrm{Mg}$ is a natural constituent of hydroxyapatite present in peritubular and intertubular dentin. Magnesium is the first element to be lost during dentin demineralization process, even prior to $\mathrm{Ca}$ and $P$ [40]. Remineralization presents restored mineral content (non-apatite) often with no $\mathrm{Mg}$ on its composition. This process occurs mainly at peritubular dentin, and less intensely in the intertubular dentin, which explains the smaller $\mathrm{Mg}$ values shown in sclerotic dentin.

Iron element was almost not detected as its amount was close to the detection level in most of the observations. The lack of difference between sound and carious dentin in the amount of iron was previously reported [41], and agrees with the present study.

\section{CONCLUSION}

It is concluded microhardness of sclerotic darkened dentin, clinically characterized, does not differ from sound dentin. Microhardness was also similar within the analyzed depths. The assessed chemical elements were similarly present in sound or sclerotic dentin, except for $\mathrm{Mg}$, which was present higher concentration in sound dentin, and for $\mathrm{Ca}$ and $\mathrm{P}$, being lower in superficial sclerotic dentin.

\section{REFERENCES}

1. Row L, Repp MR, Kingsley K. Screening of a Pediatric and Adult Clinic Population for Caries Pathogen Scardovia Wiggsiae. J Clin Pediatr Dent. 2016;40(6):438-44.

2. Foxman B, Luo T, Srinivasan U, Ramadugu K, Wen A, Goldberg D, et al. The effects of family, dentition, and dental caries on the salivary microbiome. Ann Epidemiol. 2016;26(5):348-54.

3. Bagramian RA, Garcia-Godoy F, Volpe AR. The global increase in dental caries. A pending public health crisis. Am J Dent. 2009;22(1):3-8.

4. Bjørndal L. Buonocore Memorial Lecture. Dentin caries: progression and clinical management. Oper dent. 2001;27(3):211-7.

5. Loesche WJ. Clinical and microbiological aspects of chemotherapeutic agents used according to the specific plaque hypothesis. J Dent Res. 1979;58(12):2404-12.

6. Handelman S, Washburn F, Wopperer P. Two-year report of sealant effect on bacteria in dental caries. J Am Dent Assoc. 1976;93(5):967-70.

7. Mertz-Fairhurst EJ, Curtis JW, Ergle JW, Rueggeberg FA, Adair SM. Ultraconservative and cariostatic sealed restorations: results at year 10. J Am Dent Assoc. 1998;129(1):55-66.

8. Tassery H, Levallois B, Terrer E, Manton DJ, Otsuki M, Koubi S, et al. Use of new minimum intervention dentistry technologies in caries management. Australian dental journal. 2013;58 Suppl 1:40-59.

9. Bjørndal L, Larsen T, Thylstrup A. A clinical and microbiological study of deep carious lesions during stepwise excavation using long treatment intervals. Caries Res. 1997;31(6):411-7.

10. Kidd E, Ricketts D, Pitts N. Occlusal caries diagnosis: a changing challenge for clinicians and epidemiologists. J Dent. 1993;21(6):323-31.

11. Maltz M, de Oliveira EF, Fontanella V, Bianchi R. A clinical, microbiologic, and radiographic study of deep caries lesions after incomplete caries removal. Quintessence Int. 2002;33(2).

12. Gu F, Bresciani E, Barata T, Fagundes T, Navarro M, Dickens S, et al. In vivo acid etching effect on bacteria within caries-affected dentin. Caries Res. 2010;44(5):472-7.

13. Zheng L, Nakajima M, Higashi T, Foxton RM, Tagami J. Hardness and Young's modulus of transparent dentin associated with aging and carious disease. Dental materials journal. 2005;24(4):648-53.

14. Terrer E, Koubi S, Dionne A, Weisrock G, Sarraquigne C, Mazuir $A$, et al. A new concept in restorative dentistry: light-induced fluorescence evaluator for diagnosis and treatment. Part 1: 
Diagnosis and treatment of initial occlusal caries. The journal of contemporary dental practice. 2009;10(6):E086-94.

15. Silva PF, de Holanda Ferreira DA, Meira KR, Forte FD, Chaves AM, de Sousa FB. Dentin reactions to caries are misinterpreted by histological "gold standards". F1000Research. 2014;3:13.

16. Terrer E, Panayotov IV, Slimani A, Tardivo D, Gillet D, Levallois B, et al. Laboratory Studies of Nonlinear Optical Signals for Caries Detection. J Dent Res. 2016;95(5):574-9

17. Wang Z, Jiang T, Sauro S, Pashley DH, Toledano M, Osorio R, et al The dentine remineralization activity of a desensitizing bioactive glass-containing toothpaste: an in vitro study. Australian dental journal. 2011;56(4):372-81.

18. Bjørndal L, Larsen T. Changes in the cultivable flora in deep carious lesions following a stepwise excavation procedure. Caries Res. 2000;34(6):502-8.

19. Craig R, Gehring P, Peyton F. Relation of structure to the microhardness of human dentin. Journal of Dental Research. 1959;38(3):624-30.

20. Kinney J, Marshall S, Marshall G. The mechanical properties of human dentin: a critical review and re-evaluation of the denta literature. Crit Rev Oral Biol Med. 2003;14(1):13-29.

21. Castanho GM, Marques MM, Marques JB, Camargo MA, Cara AAD. Micromorphological and hardness analyses of human and bovine sclerotic dentin: a comparative study. Braz Oral Res. 2011;25(3):274-9

22. Martin N, Garcia A, Vera V, Garrido MA, Rodríguez J. Mechanical characterization of sclerotic occlusal dentin by nanoindentation and nanoscratch. Am J Dent. 2010;23(2):108.

23. Ogawa K, Yamashita Y, Ichijo T, Fusayama T. The ultrastructure and hardness of the transparent of human carious dentin. J Dent Res. 1983:62(1):7-10.

24. Bjørndal L, Larsen T, Thylstrup A. A clinical and microbiological study of deep carious lesions during stepwise excavation using long treatment intervals. Caries Research. 1997;31(6):411-7.

25. Bjørndal L, Fransson H, Bruun G, Markvart M, Kjaeldgaard M, Nasman P, et al. Randomized Clinical Trials on Deep Carious Lesions: 5-Year Follow-up. J Dent Res. 2017;96(7):747-53.

26. Djomehri SI, Candell S, Case T, Browning A, Marshall GW, Yun W, et al. Mineral density volume gradients in normal and diseased human tissues. PloS one. 2015;10(4):e0121611.

27. Magnus L, Maltz M, Bavaresco C, F. Bastos L, N. Hashizume L. Biochemical composition of carious dentin and different layers of sound dentin. J Oral Sci. 2013;55(2):133-7.
28. Arnold W, Konopka S, Gaengler P. Qualitative and quantitative assessment of intratubular dentin formation in human natural carious lesions. Calcif Tissue Int. 2001;69(5):268.

29. Lakomaa E-L, Rytömaa I. Mineral composition of enamel and dentin of primary and permanent teeth in Finland. Eur J Oral Sci. 1977;85(2):89-95

30. Adegboye AR, Fiehn NE, Twetman S, Christensen LB, Heitmann BL Low calcium intake is related to increased risk of tooth loss in men. The Journal of Nutrition. 2010;140(10):1864-8.

31. Arnold W, Gaengler P. Quantitative analysis of the calcium and phosphorus content of developing and permanent human teeth. Ann Anat. 2007;189(2):183-90.

32. Levine R. The differential inorganic composition of dentine within active and arrested carious lesions. Caries Res. 1973;7(3):245-60.

33. Derise NL, Ritchey S. Mineral composition of normal human ename and dentin and the relation of composition to dental caries: II. Microminerals. J Dent Res. 1974;53(4):853-8.

34. Ricomini Filho AP, Tenuta LMA, Fernandes FSdF, Calvo AFB Kusano SC, Cury JA. Fluoride concentration in the top-selling Brazilian toothpastes purchased at different regions. Braz Dent J. 2012;23(1):45-8.

35. Kinney J, Marshall S, Marshall G. The mechanical properties of human dentin: a critical review and re-evaluation of the dental literature. Critical Reviews in Oral Biology \& Medicine. 2003;14(1):13-29.

36. Kinney JH, Balooch M, Marshall SJ, Marshall GW, Jr., Weihs TP. Hardness and Young's modulus of human peritubular and intertubular dentine. Arch Oral Biol. 1996;41(1):9-13.

37. Landis WJ. The strength of a calcified tissue depends in part on the molecular structure and organization of its constituent mineral crystals in their organic matrix. Bone. 1995;16(5):533-44.

38. Angker L, Nockolds C, Swain MV, Kilpatrick N. Quantitative analysis of the mineral content of sound and carious primary dentine using BSE imaging. Arch Oral Biol. 2004;49(2):99-107.

39. Sajithlal G, Chithra P, Chandrakasan G. An in vitro study on the role of metal catalyzed oxidation in glyeation and crosslinking of collagen. Mol Cell Biochem. 1999;194(1-2):257-63.

40. Daculsi G, LeGeros R, Jean A, Kerebel B. Possible physico-chemical processes in human dentin caries. J Dent Res. 1987;66(8):1356-9.

41. Gierat-Kucharzewska B, Braziewicz J, Majewska U, Gozdz S, Karasinski A. Concentration of selected elements in the roots and crowns of both primary and permanent teeth with caries disease. Biol Trace Elem Res. 2003;96(1-3):159-67.

\section{Prof. Dr. Eduardo Bresciani (Corresponding address)}

Instituto de Ciência e Tecnologia, UNESP -

Departamento de Odontologia Restauradora

Av. Eng. Francisco José Longo, 777 .

São Jose dos Campos, SP, Brasil - 12245-000

Telephone: +55 1239479000

Fax: +55 1239479010

Date submitted: 2017 Mar 21

E-mail: eduardob@ict.unesp.br 